\title{
Improving the efficiency of managing the modes of distributive networks by automated monitoring the parameters of the mode and the environment in real time
}

\author{
Nikolai Cheremisin, \\ Oleksandr Savchenko, \\ Stanislav Diubko \\ Kharkiv Petro Vasylenko \\ National Technical University of Agriculture \\ Kharkiv, Ukraine
}

\author{
Olexsiy Iegorov, \\ O. M. Beketov National University of Urban Economy in \\ Kharkiv, Ukraine
}

\begin{abstract}
Annotation - The article deals with monitoring of power lines in areas with intensive ice deposition. It emphasizes the need to apply environmental parameters that significantly affect the short-term forecast of electricity consumption, energy losses in power grid elements, frostbite on power lines and their forecasting, outlines the main tasks that are solved by an automated monitoring system. It is proposed to improve the existing monitoring systems for power lines by adding meteorological parameters to the system. It is shown that monitoring of power lines, taking into account real-time monitoring of meteorological data, will allow to increase the efficiency of management of the modes of operation of electric networks
\end{abstract}

For this purpose it is necessary to include in the automated system of monitoring of parameters of power lines additional blocks of control of environmental parameters. Observation data generated in the relevant database will be used to analyze, evaluate, and forecast the weather to correct system management.

An automated system for monitoring power and meteorological parameters should be a multifunctional system. This will make it possible to make greater use of the laid-down power lines (mechanical, electrical) and to make adequate management decisions in normal and emergency modes. The use of meteorological data will allow monitoring of environmental meteorological parameters in the area where the power lines are located and, accordingly, to control their current state, which will allow to optimize the use of their real throughput, to control the level of technological losses, to perform limit values of long and short-term currents, and overload currents. capacity along power lines, and to assess weather conditions in a particular area for emergency crews.

The organization of monitoring of power lines taking into account the control of weather data in real time will allow to increase the efficiency of management of the modes of operation of the electrical networks.

Key words - electric networks, monitoring system, meteorological parameters, ice deposits, short circuits.

\section{INTRODUCTION}

The new capabilities of existing information technologies make it possible to move to more efficient management and operation of electric networks by monitoring data on environmental parameters that significantly affect the short-term forecast of electricity consumption, the energy loss in grid elements, icing accretion on power lines (PL). This requires to include additional environmental monitoring blocks in the automated monitoring system of the overhead line parameters. The observational data generated in the relevant database will be used for their analysis, assessment and prediction of the meteorological situation with the aim of correcting the management of the system.

An automated monitoring system for the parameters of overhead lines and meteorological parameters should be a multifunctional system. This will make it possible to use mechanical and electrical resources to a greater extent, and also to make the correct control decisions in the normal and emergency modes (melting ice [5-10], load control of a power system, search for short-circuit (SC), etc.).

Recently, electric power organizations are increasingly using various monitoring systems for overhead lines, providing the system operator with detailed information on the current state of overhead lines [1-4]. The existing differences of such systems are associated, as a rule, only with an element base, while the functionality is similar.

One of the examples of such systems is monitoring system of distribution electric networks [14]. This system is designed for early detection of ice on the overhead lines, monitoring the magnitude of the load and a number of meteorological parameters (temperature, humidity, direction and wind speed) at the point of installation of the control point. The disadvantage of this system is a narrow range of functionality.

The purpose of the article is to improve efficiency of monitoring overhead lines in areas with intensive deposition of ice due to the expansion of the functionality of the system in any emergency situations. 


\section{PROPOSED DIRECTIONS}

The automated monitoring system for the parameters of overhead lines and meteorological parameters should provide the following functions [13]:

- $\quad$ short-term and long-term forecasting of power consumption;

- $\quad$ short-term and long-term forecasting of energy consumption in the tasks of managing the efficiency of consumption processes (energy management tasks);

- prevention of damage due to the formation of ice (breakage of wires, damage to support structures) by timely alerting operational personnel to the possibility and the fact of ice formation;

- increase of accuracy of calculation of losses of electric energy in problems of dispatching management;

\section{A. Main Tasks}

Among the main tasks that are solved by the automated monitoring system for the parameters of PL and meteorological parameters should be:

- tasks of automatic periodic measurement of meteorological parameters;

- $\quad$ tasks of receiving, processing and storing parameters in the database;

- $\quad$ analysis tasks and generation of warnings;

- $\quad$ control of melting ice;

- tasks of real-time data transmission to the dispatcher's workstation.

The solution of these tasks should be carried out within the framework of a system for collecting meteorological parameters from meteorological stations [13].

In contrast to existing approaches, monitoring of meteorological parameters should be carried out on PL using the meteorological stations, and they can include both traditional sensors of meteorological parameters (air temperature, humidity, air speed, air direction), and new type sensors - mass sensors of ice deposits.

The parameters must be measured and transmitted to the workstation at least once every 30 minutes, and the interval between measurements must dynamically change depending on the meteorological situation.

Duration of measurement for:

- $\quad$ air temperature, relative humidity, mass sensors of ice deposits -3 s.;

- $\quad$ air speed, air direction -2 minutes with a data acquisition rate of $3 \mathrm{~s}$.

The system for collecting meteorological parameters from meteorological stations should:

- $\quad$ providing acceptance of these parameters;

- to carry out their verification (verification for reliability);

- $\quad$ to monitor the weather situation and support decision-making;
-

to maintain a database of meteorological parameters.

Weather meteorological monitoring includes forecasting of meteorological parameters based on statistical analysis, displaying current and forecasted weather conditions in the user's interface.

\section{The Decision-Making System}

The decision-making system includes an assessment of the probability of ice formation, the generation of alarm messages to operational personnel when exceeding the limit criteria insertions.

To implement the tasks, the automated monitoring system for meteorological parameters should perform the following functions:

- measurements with a given accuracy of meteorological parameters taking into account interference protection;

- retransmission of meteorological parameters;

- display in real-time the meteorological situation on the territory of the power grid;

- $\quad$ short-term and long-term forecasting of electricity consumption;

- forecasting of the deposition of ice on the PL and timely warning of operational personnel about this situation;

- $\quad$ prevention of accidents caused by breakage of overhead lines and damages of other structures of electrical networks under the influence of wind and ice;

- accumulation of meteorological data for statistical analysis and for accounting in project practice.

The network of meteorological stations on the overhead line will provide monitoring of the meteorological situation not only for individual points of the power grid, but also for the entire territory of the network as a whole.

Since the weather data are linked to the map of the locality, it is necessary to solve the problem of storing and presenting meteorological data using specially geoinformation systems (GIS) specially designed for this purpose, which are increasingly used in the management of energy objects. Data coming from the monitoring system should be used to take into account the effect of weather conditions on the current and predicted value of the technological consumption of electricity, as well as the structure of the technological consumption of electricity by various elements of the power grid:

- real-time data on the meteorological situation in the area of passing overhead lines allow for more precise planning of the operations of operational brigades. The monitoring data in combination with GIS technology will be used most effectively;

- real-time meteorological data allow to increase the accuracy of calculating corona discharge losses by 2 to 6 times;

- $\quad$ taking into account the effect of ambient temperature on losses, relative and absolute wear of hard insulation will increase the accuracy of loss calculation by $20-50 \%$, 
Nikolai Cheremisin, Oleksandr Savchenko, Stanislav Diubko, Olexiy legorov Вип.54, № 01.

plan repair activities not only in accordance with existing standards, but also taking into account the real state of the equipment.

\section{The Structure of the Technical Complex}

The structure of the technical means complex of the automated monitoring system for the parameters of overhead lines and meteorological parameters should include three levels: lower, middle and upper [14].

Lower - the level of collection and processing of data. At this level, there are sensors and primary converters. Here, the measured physical parameters are converted into unified signals for the transfer of measurement data to the middle level.

Middle - controllers and input/output devices. At this level, signals are processed from the lower level, calcula- tions of a number of parameters are performed, and digital streams are formed to transfer information to the upper level.

Upper - level of processing and presentation of meteorological data. At this level, digital streams are collected and processed, archives maintained, expert evaluations performed, information displayed on the monitor screen.

As channels of information transfer in the monitoring system can be used: radio channel with the type of FFSK modulation, GSM-communication, fiber-optic communication line, satellite communication channel, communication based on the technology of PLC.

The architecture of the software environment of the automated monitoring system of the overhead line can be viewed as shown in Fig. 1

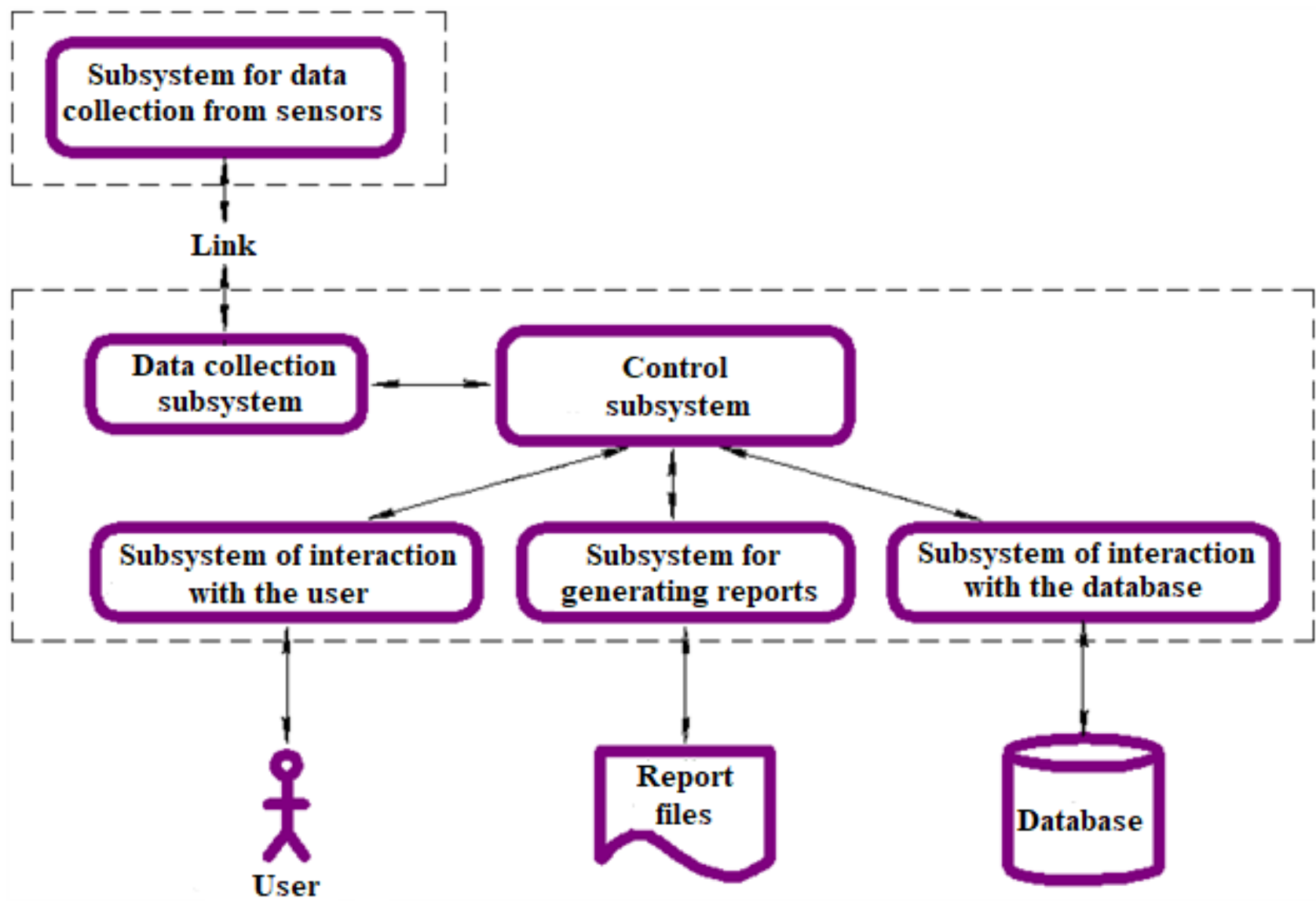

Fig. 1. Architecture of the monitoring system software

\section{MONITORING FAULT LOCATIONS}

\section{A. Indicators}

Today, it is advisable to create automated monitoring systems for overhead lines using modern technical means of collecting, transmitting and processing information. The automated monitoring system must have multifunctional software that is compatible with existing software. A modular view of the system should also be provided, which will allow it to be integrated into the general automated system for controlling the technological process of electric power transmission [13].
An automated monitoring system for the parameters of overhead lines and meteorological parameters can be constructed on the basis of monitoring fault locations of 3-35 $\mathrm{kV}$ overhead lines based on the use of short-circuit indicators (Fig. 2) [16].

The indicators are powered by long life batteries. Each indicator is equipped with an internal battery diagnostic system. The indicator includes a radio transmitter for transmitting information on the fact of operation and the type of damage to the control center. In this case, on the support near the installation of indicators, a transmitter is 
mounted, which, having received information from the indicators, retransmits it via GSM-channel.

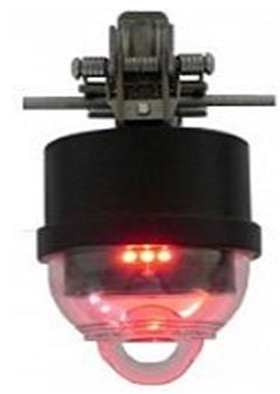

Fig. 2. Short-circuit indicators for overhead lines with integrated meteorological sensor.
This system is an effective tool for solving such an important task for the energy sector as finding short-circuit places in distribution electric networks. But if the system is supplemented with sensors that control meteorological data, as well as sensors for the ice deposits in the area where the overhead line passes, the list of tasks that the system will solve will significantly expand.

\section{B. Using of Meteorological Data}

The use of meteorological data will allow monitoring of meteorological parameters of the environment in the area where PL is located and, accordingly, to monitor their current state, which will allow optimizing the use of their real throughput, monitoring the level of technological losses, assessing the limits of long and short-time load currents.

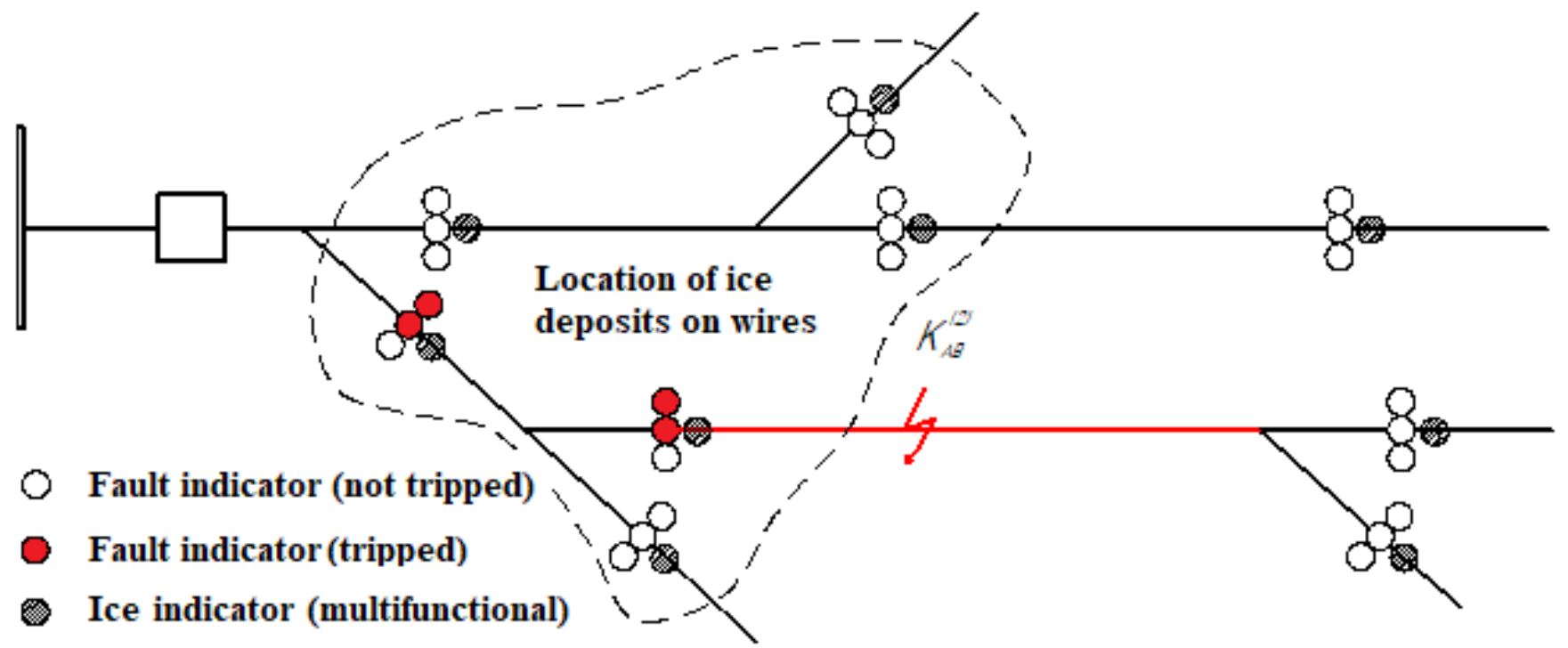

Fig. 3. Determination of failure location of the overhead line

Sensors for detecting the presence of deposition of ice on the wires, which are installed together with the shortcircuit indicators to the overhead line, will solve the problem of determining the places of ice formation in electrical networks. Since the formation of ice deposits on the wires of the overhead line is random and can not cover the entire length of the line, but only some individual sections of the line or a branch, the definition of the places of deposition of ice will be a very actual function.

An automated monitoring system for the parameters of overhead lines and meteorological parameters should be closely related to predicting the probability of ice accumulation on the overhead lines [14-16]. At the same time, predictive functions should be implemented with the help of various programs are like "dispatcher advisers".

\section{CONCLUSION.}

The monitoring of overhead lines, taking into account real-time monitoring of meteorological data, will improve the efficiency of managing the operating modes of electric networks through short-term and long-term forecasting of power consumption, preventing accidents associated with the formation of ice on the overhead lines by timely alerting operational personnel to the possibility of ice, mode of melting sediments, increasing the accuracy of calculating the loss of electrical energy and finding places short circuits in problems of dispatching management.

\section{REFERENCES}

[1] V. Bashkevich, G. Ugarov, "Monitoring of ice-wind and temperature loads of overhead transmission lines", Electricity and the future of civilization, Tomsk, 2004.

[2] I. Levchenko, E. Satsuk, "Software complex for calculating and controlling the melting of ice on the overhead transmission line", Electrical Engineering 2010, Volume 1, 2.21., 2003.

[3] I. Levchenko, E. Satsuk, "Software for the detection and melting of ice on a 10-500 kV overhead line" Proceedings of high schools. Electromechanics, № 6, 2002.

[4] I. Levchenko, A. Zasypkin, A. Alliluyev, "Satsuk Diagnosis, reconstruction and operation of overhead transmission lines in ice regions", Izdatelstvo MEI, Moscow, 430 p., 2007.

[5] I. Bilash, O. Savchenko, O. Parkhomenko, "Tasks of monitoring of overhead transmission lines in iced areas", KhNTUSG, Kharkiv, Issue. 117, pp.13-15, 2011.

[6] M. Cheremisin, V. Zubko, O. Parkhomenko, V. Bula, V. Khomenko, A. Hrytsenko, "Device for controlling the load of power lines from icing" Patent. 91310 Ukraine, MKV N $02 \mathrm{H} \mathrm{7/00,}$ 2010.

[7] M. Cheremisin, S. Popov, O. Savchenko, K. Shkuro, O. Parkhomenko, "Efficiency of monitoring of overhead transmission lines in iced areas", Scientific works of Donetsk National Technical University, Donetsk, No. 2 (15), pp. 261-264, 2013.

[8] O. Savchenko, S. Dudnikov, "Tactics of behavior of personnel of electric networks in the conditions of formation of ice on the PL", 
Nikolai Cheremisin, Oleksandr Savchenko, Stanislav Diubko, Olexiy legorov Вип.54, № 01.

Taurian State Agrotechnological University, Melitopol, Issue 13, t.5, pp. 58-61, 2013.

[9] O. Iegorov "On the issue of calculating the dynamic modes of the electric system" // Collection of scientific works of Kharkiv University of Air Forces. - 2010. - №. 4. - C. 172-174

[10] G. Gruba, O. Parkhomenko, V. Bulaga, V. Khomenko, A. Gritsenko, N. Cheremisin, A. Savchenko, "Monitoring of ice conditions in the electric grids of Krymenergo", Power and electrification., No. 2, pp. 31-35, 2012.

[11] M. Cheremisin, I. Bilash, O. Savchenko "Substantiation of parameters of melting schemes on ice on 6-10 kV PL 6 distribution networks based on fuzzy modeling", Power engineering and electrification, No. 9, pp. 33-37, 2010.

[12] O. Iegorov. "Nvestigation of pulse power through single phase loads on the earth in networks 6-10 kv"//International Scientific and Practical Conference World science - ROST, 2016 - T. 1. №. 1. - C. 18-20.

[13] O. Savchenko, S. Diubko, "Perspective ways to improve automated control systems for the formation of ice on the PL", KhNTUSG, Kharkiv, pp. 20 - 22, 2016

[14] N. Titov, M. Dotsenko, S. Dotsenko "Formation of a departmenta meteorological data collection system in an efficient wholesale electricity market", Institute of Electrodynamics of the National Academy of Sciences of Ukraine, Kyiv, pp. 41-48, 2009.

[15] O. Moroz, M. Cheremisin, O. Savchenko, S. Popadchenko, S Diubko, "The use of Smart Grid technologies to increase the efficiency of consumer power supply", Power engineering: economics, technology, ecology, Kyiv, pp. 45 - 49, 2017.

[16] "Indicator of damage to the air line FI-3A2F". Available: https://relematika.ru/produkty/6-35_kv/indikator-fi-3a2f.

\section{Improving the efficiency of managing the modes of} distributive networks by automated monitoring the parameters of the mode and the environment in real time

\author{
Nikolai Cheremisin, Oleksandr Savchenko, \\ Stanislav Diubko
}

Kharkiv Petro Vasylenko National Technical University of Agriculture

Kharkiv, Ukraine
Olexiy Iegorov,

O. M. Beketov National University of Urban Economy in Kharkiv, Ukraine

The article deals with monitoring of power lines in areas with intensive ice deposition. It emphasizes the need to apply environmental parameters that significantly affect the short-term forecast of electricity consumption, energy losses in power grid elements, frostbite on power lines and their forecasting, outlines the main tasks that are solved by an automated monitoring system. It is proposed to improve the existing monitoring systems for power lines by adding meteorological parameters to the system. It is shown that monitoring of power lines, taking into account real-time monitoring of meteorological data, will allow to increase the efficiency of management of the modes of operation of electric networks

For this purpose it is necessary to include in the automated system of monitoring of parameters of power lines additional blocks of control of environmental parameters. Observation data generated in the relevant database will be used to analyze, evaluate, and forecast the weather to correct system management.

An automated system for monitoring power and meteorological parameters should be a multifunctional system. This will make it possible to make greater use of the laid-down power lines (mechanical, electrical) and to make adequate management decisions in normal and emergency modes. The use of meteorological data will allow monitoring of environmental meteorological parameters in the area where the power lines are located and, accordingly, to control their current state, which will allow to optimize the use of their real throughput, to control the level of technological losses, to perform limit values of long and short-term currents, and overload currents. capacity along power lines, and to assess weather conditions in a particular area for emergency crews.

The organization of monitoring of power lines taking into account the control of weather data in real time will allow to increase the efficiency of management of the modes of operation of the electrical networks.

Keywords - electric networks, monitoring system, meteorological parameters, ice deposits, short circuits.

\section{Підвищення ефективності управління режимами розподільних мереж за рахунок автоматизованого моніторингу параметрів режиму та навколишнього середовища у реальному часі}

М.М. Черемісін, О.А. Савченко, С.В. Дюбко Харківський національний технічний університет сільського господарства імені Петра Василенка, Україна

\author{
О.Б. Єгоров \\ Харківський національний університет міського гос- \\ подарства імені О.М. Бекетова, Україна
}

\footnotetext{
У статті розглядається моніторинг повітряних ліній в районах з інтенсивним осадженням льоду. Наголошується на необхідності застосування параметрів навколишнього середовища, які суттєво впливають на короткостроковий прогноз споживання електроенергії, втрати енергії в елементах енергосистеми, обмерзання на лініях електропередач та їх прогнозування, описані основні завдання, які вирішуються автоматизованою системою моніторингу. Запропоновано вдосконалити існуючі системи моніторингу для повітряних ліній шляхом додавання до системи показників, що визначають метеорологічні параметри. Показано, що моніторинг повітряних ліній з урахуванням моніторингу в реальному часі метеорологічних даних дозволить підвищити ефективність управління режимами роботи електричних мереж
} 
Для цього необхідно в автоматизовану систему моніторингу параметрів повітряних ліній включити додаткові блоки контролю параметрів навколишнього середовища. Дані спостережень, сформовані у відповідній базі даних, будуть використовуватись для їх аналізу, оцінки та прогнозування метеорологічної обстановки з метою корекції управління системою.

Автоматизована система моніторингу параметрів повітряних ліній та метеопараметрів повинна бути багатофункціональною системою. Це дасть можливість у більшій мірі використовувати закладені ресурси повітряних ліній (механічні, електричні), а також приймати адекватні керуючі рішення в нормальному та аварійному режимах. Використання метеоданих дозволить проводити моніторинг метеопараметрів навколишнього середовища в районі, де знаходиться повітряні лінії, і відповідно, контролювати їх поточний стан, що дозволить оптимізувати використання їх реальної пропускної здатності, контролювати рівень технологічних втрат, виконувати оцінку граничних значень тривалих і короткочасних струмів навантаження, регулювати перетоки потужності по повітряних лініях, а також давати оцінку погодним умовам в певному районі для аварійних бригад.

Організація моніторингу повітряних ліній з урахуванням контролю метеоданих в режимі реального часу дозволить підвищити ефективність керування режимами роботи електричних мереж.

Ключові слова - електричні мережі, система моніторингу, метеорологічні параметри, відкладення льоду, короткі замикання. 